\title{
EVALUASI KINERJA KEUANGAN PEMERINTAH DAERAH KABUPATEN MUSI BANYUASIN MELALUI PENDEKATAN VALUE FOR MONEY
}

\author{
Ahmad Irfansyah \\ STIE Rahmaniyah Sekayu \\ email:irfansyahahmad2@gmail.com \\ Jumania Septariani \\ STIE Rahmaniyah Sekayu \\ Email:jseptariani@gmail.com
}

\begin{abstract}
The purpose of this study was to determine the regional financial performance of the Regional Government of Musi Banyuasin Regency in terms of the value for money approach. Types and sources of data used by the author in this study are secondary data. The results of the study stated that the Government of Musi Banyuasin Regency applied Value for Money as a concept of measuring its performance. With the concept of Value for Money, the government measures organizational performance more comprehensively, so that the government improves its performance in the future. The economic ratio of the Musi Banyuasin Regency Government showed the performance of the regional government in 2015 to 2019 with an average ratio of $87.08 \%$, indicating that this ratio is of economic value. The performance efficiency ratio of the Musi Banyuasin Regency Government was quite good. In 2016 to 2019 was efficient, although in 2015 it showed an inefficient ratio. The effectiveness ratio in the Musi Banyuasin Regency Government for the period 2015 to 2019 with an average ratio value of $94.78 \%$, the effectiveness ratio of $<100 \%$ indicating that the performance of the Musi Banyuasin Regency government in that year was considered ineffective.
\end{abstract}

Keywords: Financial Performance, Value For Money, Economics, Efficiency, Effectiveness

\section{PENDAHULUAN}

Pengukuran kinerja merupakan faktor penting di dalam suatu organisasi, termasuk juga untuk organisasi sektor publik. Pengukuran kinerja sangat diperlukan untuk menilai akuntabilitas organisasi dalam menghasilkan pelayanan publik yang lebih baik dan tepat sasaran. Pengukuran kinerja sektor publik dilakukan untuk memenuhi tiga maksud. Pertama, pengukuran kinerja sektor publik dimaksudkan untuk membantu memperbaiki kinerja pemerintah. Kedua, ukuran kinerja sektor 
publik digunakan untuk pengalokasian sumber daya dan pembuatan keputusan. Ketiga, ukuran kinerja sektor publik dimaksudkan untuk mewujudkan pertanggungjawaban publik dan memperbaiki komunikasi kelembagaan. Ukuran kinerja pemerintah daerah berdasarkan anggaran berbasis kinerja dapat diukur menggunakan konsep value for money, yakni ekonomis, efisiensi, dan efektivitas.

Value for Money merupakan konsep pengelolaan organisasi sektor publik yang mendasarkan pada tiga elemen utama, yaitu ekonomi, efisiensi dan efektifitas. Elemen pertama dari konsep value for money yaitu ekonomi. Ekonomi adalah pemerolehan input dengan kualitas dan kuantitas tertentu pada harga yang terendah. Ekonomi terkait dengan sejauh mana organisasi sektor publik dapat meminimalisir input resources yang digunakan yaitu dengan menghindari pengeluaran yang boros dan tidak produktif. Elemen kedua dari konsep value for money ialah efisiensi. Efisiensi yaitu pencapaian output dengan input tertentu atau penggunaan input yang terendah untuk mencapai output tertentu. Semakin rendah nilai rasio efisiensi yang di peroleh, maka semakin bagus pula kinerja organisasi sektor publik tersebut. Elemen yang terakhir dari konsep value for money yaitu efektifitas. Efektivitas adalah tingkat pencapaian hasil program dengan target yang ditetapkan. Secara sederhana, efektifitas merupakan perbandingan outcome dengan output.

Kabupaten Musi Banyuasin adalah salah satu dari 16 kabupaten/kota yang ada di Sumatera Selatan dengan ibu kota Kota Sekayu yang memiliki luas wilayah $\pm 14.265,96 \mathrm{~km}^{2}$ yang terbentang pada lokasi $1,3^{\circ}-4^{\circ} \mathrm{LS}, 103^{\circ}-105^{\circ} \mathrm{BT}$, di Kabupaten Musi Banyuasin. Kabupaten Musi Banyuasin mengatur dan mengurus sendiri urusan pemerintahan serta mendapatkan kebebasan untuk mengolah dan meningkatkan sumber pendapatan daerahnya, demi kesejahteraan masyarakat dan kemajuan daerahnya. Badan Pengelolaan Keuangan dan Aset Daerah (BPKAD) Kabupaten Musi Banyuasin merupakan badan daerah yang memegang peranan dan fungsi strategis di bidang pengelolaan keuangan dan aset daerah Kabupaten Musi Banyuasin. Pengelolaan Anggaran Pendapatan dan Belanja Daerah (APBD) Kabupaten Musi Banyuasin memiliki pola yang jelas dan jumlah anggaran yang semakin besar. Tahun anggaran 2015-2017, prioritas APBD adalah meningkatkan pelayanan publik. Sedangkan Tahun 2018 dan 2019, diarahkan pada peningkatan 
pembangunan infrastruktur untuk memacu ekonomi dan kesejahteraan masyarakat.

Berikut ini adalah data tentang Anggaran Pendapatan dan Belanja Daerah (APBD)

Kabupaten Musi Banyuasin yang disajikan pada Tabel 1.

Tabel 1

Pemerintah Kabupaten Musi Banyuasin

Anggaran dan Realisasi Pendapatan dan Belanja Daerah

(Dalam Rupiah)

\begin{tabular}{|c|c|c|c|c|c|c|}
\hline \multirow{2}{*}{ Tahun } & \multicolumn{3}{|c|}{ Pendapatan Daerah } & \multicolumn{3}{c|}{ Belanja Daerah } \\
\cline { 2 - 7 } & Anggaran & Realisasi & $\%$ & Anggaran & Realisasi & $\%$ \\
\hline \hline 2015 & 2.506 .193 .141 .320 & 2.034 .401 .344 .567 & 81,17 & 2.601 .478 .000 .000 & 2.096 .431 .426 .307 & 80,59 \\
\hline 2016 & 2.849 .225 .683 .981 & 2.640 .255 .197 .404 & 92,67 & 2.516 .296 .929 .956 & 2.280 .009 .346 .065 & 90,61 \\
\hline 2017 & 2.876 .720 .007 .058 & 2.642 .776 .006 .641 & 91,87 & 2.566 .618 .015 .238 & 2.340 .644 .994 .246 & 91,20 \\
\hline 2018 & 2.979 .978 .607 .000 & 3.019 .699 .825 .935 & 101,33 & 3.082 .227 .677 .300 & 2.569 .468 .000 .595 & 83,36 \\
\hline 2019 & 3.688 .474 .554 .548 & 3.941 .909 .794 .940 & 106,87 & 3.525 .077 .794 .799 & 3.160 .193 .342 .676 & 89,65 \\
\hline
\end{tabular}

Sumber: BPKAD Kabupaten Musi Banyuasin, Tahun 2020, data diolah

Berdasarkan Tabel 1 di atas, dapat dilihat bahwa realisasi pendapatan Kabupaten Musi Banyuasin dari Tahun 2015 sampai dengan 2017 tidak melampaui target dan Tahun 2018 sampai 2019 selalu melampaui anggaran yang telah ditentukan yaitu realisasi. Sedangkan realisasi belanja Kabupaten Musi Banyuasin dari Tahun 2015 sampai dengan 2019 lebih rendah dibandingan dengan belanja yang dianggarkan. Dilihat dari perbandingan antara realisasi pendapatan dan belanja daerah Kabupaten Musi Banyuasin bahwa realisasi pendapatan daerah dari Tahun 2015 sampai dengan 2019 cenderung mengalami surplus anggaran dimana pendapatan daerah lebih besar dari belanja daerah. Hal ini dikarenakan terjadi pengurangan pagu dana belanja daerah. Hal ini menunjukkan bahwa Pemerintah Kabupaten Musi Banyuasin telah melakukan optimalisasi pendapatan daerah, tetapi belanja daerah yang telah dianggarkan sebelumnya tidak terlaksana dengan baik.

Dilihat dari perbandingan antara realisasi pendapatan dan belanja daerah Kabupaten Musi Banyuasin bahwa realisasi pendapatan daerah dari Tahun 2015 sampai dengan 2019 cenderung mengalami surplus anggaran dimana pendapatan daerah lebih besar dari belanja daerah. Hal ini dikarenakan terjadi pengurangan pagu dana belanja daerah. Hal ini menunjukkan bahwa Pemerintah Kabupaten Musi 
Banyuasin telah melakukan optimalisasi pendapatan daerah, tetapi belanja daerah yang telah dianggarkan sebelumnya tidak terlaksana dengan baik.

Berdasarkan uraian di atas, maka Penulis tertarik melakukan penelitian dengan judul Evaluasi Kinerja Keuangan Pemerintah Daerah Kabupaten Musi Banyuasin Melalui Pendekatan Value For Money, dengan rumusan masalah Bagaimana kinerja keuangan Pemerintah Daerah Kabupaten Musi Banyuasin ditinjau dari pendekatan value for money?.

\section{KAJIAN PUSTAKA}

\section{Konsep Keuangan Daerah}

Dalam arti sempit, keuangan daerah yakni terbatas pada hal-hal yang berkaitan dengan APBD. Menurut Halim (2017:18), keuangan daerah dapat diartikan sebagai semua hak dan kewajiban pemerintah yang dapat dinilai dengan uang, demikian pula segala sesuatu baik berupa uang maupun barang yang dapat dijadikan kekayaan daerah yang lebih tinggi serta pihak-pihak lain sesuai peraturan undang-undang yang berlaku. Berdasarkan Peraturan Pemerintah Nomor 58 Tahun 2005 tentang Pengelolaan Keuangan Daerah, keuangan daerah adalah semua hak dan kewajiban daerah dalam rangka penyelenggaraan pemerintah daerah yang dapat dinilai dengan uang termasuk di dalamnya segala bentuk kekayaan yang berhubungan dengan hak dan kewajiban tersebut. Hak dan kewajiban daerah tersebut perlu dikelola dalam suatu sistem pengelolaan keuangan daerah. Pengelolaan keuangan daerah merupakan sub sistem dari sistem pengelolaan keuangan negara dan merupakan elemen pokok dalam penyelenggaraan pemerintah daerah. Menurut Halim (2017:20), ruang lingkup keuangan daerah terdiri dari keuangan daerah yang dikelola langsung dan kekayaan daerah yang dipisahkan. Yang termasuk dalam keuangan yang dikelola langsung adalah APBD dan barangbarang inventaris milik daerah. Sedangkan keuangan daerah yang dipisahkan meliputi Badan Usaha Milik Daerah (BUMD).

\section{Pengelolaan Keuangan dan Sistem Pengukuran Kinerja Keuangan Daerah}

Dalam ketentuan umum pada Peraturan Pemerintah Nomor 58 Tahun 2005 tentang Pengelolaan Keuangan Daerah, pengelolaan keuangan daerah adalah 
keseluruhan kegiatan yang meliputi perencanaan, pelaksanaan, penatausahaan, pelaporan dan pertanggungjawaban, pengawasan daerah. Pengelolaan keuangan daerah dalam hal ini mengandung beberapa kepengurusan dimana kepengurusan umum atau yang sering disebut pengurusan administrasi dan kepengurusan khusus atau sering disebut pengurusan bendaharawan. Dalam pengelolaan anggaran/keuangan daerah harus mengikuti prinsip-prinsip pokok anggaran sektor publik. Pada Peraturan Menteri Dalam Negeri Nomor 26 Tahun 2006 tentang Pedoman Penyusunan APBD menyatakan bahwa APBD harus disusun dengan memperhatikan prinsip-prinsip pokok anggaran sektor public, yaitu Partisipasi Masyarakat, Transparansi dan Akuntabilitas Anggaran, Disiplin Anggaran, Keadilan Anggaran, Efisiensi dan Efektivitas Anggaran, Taat Azas.

Menurut Nordiawan dan Atuningtyas (2018:157), pengukuran kinerja merupakan suatu proses sistematis untuk menilai apakah pro-gram/kegiatan yang telah direncanakan telah dilaksanakan sesuai dengan rencana tersebut, dan yang lebih penting adalah apakah telah mencapai keberhasilan yang telah ditargetkan pada saat perencanaan. Menurut Mardiasmo (2017:121), sistem pengukuran kinerja sektor publik adalah sistem menilai pencapaian suatu strategi melalui alat ukur finansial dan non finansial.

\section{Konsep Value For Money}

Menurut Mardiasmo (2017:120), konsep Value for Money merupakan konsep pengelolaan organisasi sektor publik yang mendasar pada tiga elemen yaitu ekonomi, efisiensi dan efektivitas. Untuk bisa mengukur tingkat ekonomi, efisiensi dan efektivitas organisasi pemerintahan harus dapat mengetahui tingkat input, output dan outcome. Adapun yang dimaksud dengan input, output dan outcome adalah : 1). Input adalah semua jenis sumber daya masukan yang digunakan dalam suatu proses tertentu untuk menghasilkan output. 2). Output adalah hasil langsung dari suatu proses. 3). Outcome adalah dampak suatu program atau kegiatan terhadap masyarakat. Tolak ukur dalam anggaran belanja suatu organisasi, baik organisasi yang berorientasi laba (swasta) maupun organisasi nonprofit (sektor publik) adalah Value for Money yang meliputi penilaian ekonomi, efisiensi dan efektivitas. 
Mahmudi (2015:89), mengemukakan bahwa Value for Money adalah pengukuran kinerja untuk mengukur ekonomi, efisiensi, dan efektivitas suatu kegiatan, program, dan organisasi.

\section{Manfaat Implementasi dan Langkah-langkah Pengukuran Value For Money}

Mardiasmo (2017:130), menyatakan penerapan konsep value for money dalam pengukuran kinerja pada organisasi sektor publik tentunya memberikan manfaat bagi organisasi itu sendiri maupun masyarakat. Manfaat yang dikehendaki dalam pelaksanaan value for money pada organisasi sektor publik yaitu: ekonomis (hemat cermat), efisien (berdaya guna) dan efektif (berhasil guna). Mardiasmo (2017:133), menyatakan manfaat lain dari implementasi konsep value for money yaitu, meningkatkan efektivitas pelayanan publik, dalam arti pelayanan yang diberikan tepat sasaran, meningkatkan mutu pelayanan publik, menurunkan biaya pelayanan publik, alokasi belanja yang lebih berorientasi pada kepentingan publik, meningkatkan kesadaran akan uang publik (public costs awareness) sebagai akar pelaksanaan akuntabilitas publik. Menurut Mardiasmo (2017: 133), langkahlangkah pengukuran value for money,yaitu : pengukuran ekonomi dengan hanya mempertimbangkan masukan (input) yang dipergunakan, pengukuran efisiensi yang diukur dengan rasio antara output dengan input. Semakin besar output dibanding input, maka semakin tinggi tingkat efisiensi suatu organisasi, pengukuran efektifitas yang merupakan ukuran berhasil atau tidaknya suatu organisasi mencapai tujuannya, pengukuran outcome yang merupakan dampak suatu program atau kegiatan terhadap masyarakat.

\section{Pengukuran Ekonomis, Efisiensi dan Efektivitas}

Menurut Mardiasmo (2017:131), ekonomis adalah hubungan antara pasar dan masukan (cost of input). Dengan kata lain ekonomis adalah pemerolehan input dengan kualitas dan kuantitas tertentu pada harga yang terendah. Sedangkan menurut Mahmudi (2015:76), mengartikan ekonomi sebagai perbandingan antara input sekunder (bahan baku, personel dan infrastruktur) dengan input primer (kas). Konsep ekonomi sangat terkait dengan konsep biaya untuk memperoleh unit input. Ekonomi berarti sumber daya input hendaknya diperoleh dengan harga lebih rendah 
(spending less), yaitu harga yang mendekati harga pasar. Input adalah semua jenis sumber daya masukan yang digunakan dalam suatu proses tertentu untuk menghasilkan output. Input tersebut dapat berupa tenaga kerja (tenaga, keahlian, dan keterampilan), serta aset-aset seperti gedung, peralatan, dan sebagainya.

Menurut Mahsun (2016:186), pengukuran ekonomis dapat dirumuskan sebagai berikut :

$$
\text { Rasio Ekonomis }=\frac{\text { Realisasi Belanja Daerah }}{\text { Anggaran Belanja Daerah }} \times 100
$$

Adapun kriteria penilaian ekonomi kinerja keuangan adalah sebagai berikut :

Tabel 2

Kriteria Ekonomis Kinerja Keuangan

\begin{tabular}{|c|c|}
\hline Persentase Kinerja Keuangan & Kriteria \\
\hline Kurang dari $100 \%$ & Ekonomis \\
Sama dengan $100 \%$ & Ekonomis Berimbang \\
Lebih dari $100 \%$ & Tidak Ekonomis \\
\hline
\end{tabular}

Sumber : Mahsun (2016)

Menurut Mardiasmo (2017:132), efisiensi merupakan komponen dari konsep value for money, efisiensi diukur dengan antara rasio antara output dengan input. Semakin besar output dibandingkan input, maka semakin tinggi tingkat efisiensi suatu organisasi. Efisiensi adalah hubungan antara barang dan jasa (output) yang di hasilkan dengan sumber daya (input) yang digunakan untuk menghasilkan output tersebut. Suatu organisasi, program, atau kegiatan dikatakan efisien apabila mampu menghasilkan output tertentu dengan input serendah-rendahnya, atau dengan input tertentu mampu menghasilkan output sebesar-besarnya (spending well).

Menurut Mahsun (2016:187), pengukuran ekonomis dapat dirumuskan sebagai berikut :

Rasio Efisiensi $=\frac{\text { Realisasi Belanja Daerah }}{\text { Realisasi Pendapatan Daerah }} \times 100$

Adapun kriteria penilaian efisiensi kinerja keuangan adalah sebagai berikut : 
Tabel 3

Kriteria Efisiensi Kinerja Keuangan

\begin{tabular}{|c|c|}
\hline Persentase Kinerja Keuangan & Kriteria \\
\hline Kurang dari $100 \%$ & Efisien \\
Sama dengan $100 \%$ & Efisien Berimbang \\
Lebih dari $100 \%$ & Tidak Efisien \\
\hline
\end{tabular}

Sumber: Mahsun (2016)

Menurut Mardiasmo (2017:132), efektivitas pada dasarnya berhubungan dengan pencapaian tujuan atau target kebijakan (hasil guna). Efektivitas merupakan hubungan keluaran dengan tujuan atau sasaran yang harus dicapai. Efektivitas terkait dengan hubungan antara hasil yang diharapkan dengan hasil yang sesungguhnya dicapai. Efektivitas merupakan hubungan antara output dengan tujuan. Semakin besar kontribusi output terhadap pencapaian tujuan, maka semakin efektif organisasi, program, atau kegiatan. Jika ekonomi berfokus pada input dan efisiensi berfokus pada output atau proses, maka efektivitas berfokus pada outcome (hasil).

Menurut Mahsun (2016:187), pengukuran ekonomis dapat dirumuskan sebagai berikut :

Rasio Efektivitas $=\frac{\text { Realisasi Pendapatan }}{\text { Anggaran Pendapatan }} \times 100$

Adapun kriteria penilaian efektivitas kinerja keuangan adalah sebagai berikut :

Tabel 4

Kriteria Efektivitas Kinerja Keuangan

\begin{tabular}{|c|c|}
\hline Persentase Kinerja Keuangan & Kriteria \\
\hline Kurang dari $100 \%$ & Tidak Efektif \\
Sama dengan $100 \%$ & Efektif Berimbang \\
Lebih dari $100 \%$ & Efektif \\
\hline
\end{tabular}

Sumber : Mahsun (2016)

\section{METODE PENELITIAN}

\section{Lokasi Penelitian}

Dalam setiap penelitian yang dilakukan perlu adanya objek penelitian, begitu juga dengan penelitian ini. Objek penelitian ini adalah Badan Pengelola 
Keuangan dan Aset Daerah Kabupaten Musi Banyuasin, yang beralamatkan Jalan Kolonel Wahid Udin Kecamatan Sekayu Kabupaten Musi Banyuasin.

\section{Jenis dan Sumber Data Penelitian}

Jenis data yang digunakan Penulis pada penelitian ini adalah data sekunder. Data sekunder yang digunakan adalah berupa data tentang target dan realisasi penerimaan APBD Tahun 2015 sampai dengan 2019 serta struktur organisasi Badan Pengelola Keuangan dan Aset Daerah Kabupaten Musi Banyuasin.

\section{Teknik Pengumpulan Data}

Pada penelitian ini Penulis mendokumentasikan data tentang target dan realisasi penerimaan APBD Tahun 2015 sampai dengan 2019 dan struktur organisasi Badan Pengelola Keuangan dan Aset Daerah Kabupaten Musi Banyuasin. Pada penelitian ini juga Penulis menelaah teori yang bersumber dan buku teks dan jurnal yang menjadi acuan Penulis dalam membuat landasan teori.

\section{Teknik Analisis Data}

Teknik analisis data yang digunakan dalam penelitian ini adalah teknik analisis data kualitatif. Analisis kualitatif dilakukan dengan cara menghitung rasio pengukuran Ekonomis, Efisiensi, dan Efektivitas, lalu disesuaikan dengan pengukuruan kriteria pengukuran.

1. Pengukuran Ekonomis

Rasio Ekonomis $=\frac{\text { Realisasi Belanja Daerah }}{\text { Anggaran Belanja Daerah }} \times 100$

2. Pengukuran Efisiensi

Rasio Efisiensi $=\frac{\text { Realisasi Belanja Daerah }}{\text { Realisasi Pendapatan Daerah }} \times 100$

3. Pengukuran Efektivitas

Rasio Efektivitas $=\frac{\text { Realisasi Pendapatan }}{\text { Anggaran Pendapatan }} \times 100$

IV. HASIL DAN PEMBAHASAN

Evaluasi Kinerja Keuangan Daerah Pemerintah Kabupaten Musi Banyuasin Melalui Pendekatan Value For Money 
Kinerja adalah suatu tingkat dalam pencapaian dari pelaksanaan kegiatan/program untuk mewujudkan sasaran, tujuan, misi, dan visi organisasi atau perusahaan. Menurut Peraturan Pemerintah Nomor 8 Tahun 2006, kinerja adalah keluaran atau hasil dari kegiatan atau program yang hendak atau telah dicapai sehubungan dengan penggunaan anggaran dengan kuantitas dan kualitas terukur. Dengan demikian kinerja mencerminkan hasil atau prestasi kerja yang dapat dicapai oleh seseorang, unit kerja, dan atau suatu organisasi pada periode tertentu sesuai dengan wewenang dan tanggung jawabnya dalam upaya mencapai tujuan secara legal serta sesuai moral dan etika.

Konsep value for money merupakan konsep pengelolaan organisasi sektor publik yang mendasar pada tiga elemen yaitu ekonomis, efisiensi dan efektivitas. Untuk bisa mengukur tingkat ekonomis dapat dilakukan dengan cara realisasi belanja daerah dibandingkan dengan anggaran belanja daerah, sedangkan untuk mengukut tingkat efisiensi dapat dilakukan dengan cara membandingkan realisasi belanja daerah dengan realisasi pendapatan daerah dan untuk mengukur tingkat efektivitas dilakukan dengan cara membandingkan realisasi pendapatan dengan anggaran pendapatan.

\section{Analisis Rasio Ekonomis}

Konsep ekonomis sangat terkait dengan konsep biaya untuk memperoleh unit input. Ekonomis berarti sumber daya input hendaknya diperoleh dengan harga lebih rendah (spending less), yaitu harga yang mendekati harga pasar. Input adalah semua jenis sumber daya masukan yang digunakan dalam suatu proses tertentu untuk menghasilkan output. Input tersebut dapat berupa tenaga kerja (tenaga, keahlian, dan keterampilan), serta aset-aset seperti gedung, peralatan, dan sebagainya. Rumus rasio ekonomis adalah sebagai berikut:

Rasio Ekonomis $=\frac{\text { Realisasi Belanja Daerah }}{\text { Anggaran Belanja Daerah }} \times 100 \%$
berikut :

Adapun kriteria penilaian ekonomis kinerja keuangan adalah sebagai 
Tabel 5

Kriteria Ekonomis Kinerja Keuangan

\begin{tabular}{|c|c|}
\hline Persentase Kinerja Keuangan & Kriteria \\
\hline Kurang dari $100 \%$ & Ekonomis \\
Sama dengan $100 \%$ & Ekonomis Berimbang \\
Lebih dari $100 \%$ & Tidak Ekonomis \\
\hline
\end{tabular}

Sumber : Mahsun (2016)

Berdasarkan rumus perhitungan rasio ekonomis, Penulis sajikan data tentang anggaran dan realisasi belanja daerah Kabupaten Musi Banyuasin pada Tabel 6 di bawah ini:

Tabel 6

Anggaran dan Realisasi Belanja Daerah

Tahun 2015 sampai dengan 2019

(Dalam Rupiah)

\begin{tabular}{|c|c|c|}
\hline Tahun & Anggaran & Realisasi \\
\hline \hline 2015 & 2.601 .478 .000 .000 & 2.096 .431 .426 .307 \\
\hline 2016 & 2.516 .296 .929 .956 & 2.280 .009 .346 .065 \\
\hline 2017 & 2.566 .618 .015 .238 & 2.340 .644 .994 .246 \\
\hline 2018 & 3.082 .227 .677 .300 & 2.569 .468 .000 .595 \\
\hline 2019 & 3.525 .077 .794 .799 & 3.160 .193 .342 .676 \\
\hline
\end{tabular}

Sumber :BPKAD Kabupaten Musi Banyuasin, Tahun 2020, data diolah

Berikut ini Penulis sajikan data tentang rekapitulasi perhitungan rasio ekonomis Pemerintah Kabupaten Musi Banyuasin Tahun 2015 sampai dengan 2019 pada tabel di bawah ini:

Tabel 7

Rekapitulasi Perhitungan Rasio Ekonomis

Pemerintah Kabupaten Musi Banyuasin

Tahun 2015 sampai dengan 2019

(Dalam Rupiah)

\begin{tabular}{|c|c|c|c|c|}
\hline Tahun & $\begin{array}{c}\text { Anggaran Belanja } \\
\text { Daerah }\end{array}$ & $\begin{array}{c}\text { Realisasi Belanja } \\
\text { Daerah }\end{array}$ & $\begin{array}{c}\% \text { Rasio } \\
\text { Ekonomis }\end{array}$ & Kriteria \\
\hline 2015 & 2.601.478.000.000 & 2.096.431.426.307 & 80,59 & Ekonomis \\
\hline 2016 & 2.516.296.929.956 & 2.280 .009 .346 .065 & 90,61 & Ekonomis \\
\hline 2017 & 2.566 .618 .015 .238 & 2.340 .644 .994 .246 & 91,20 & Ekonomis \\
\hline 2018 & 3.082 .227 .677 .300 & 2.569 .468 .000 .595 & 83,36 & Ekonomis \\
\hline 2019 & 3.525 .077 .794 .799 & 3.160 .193 .342 .676 & 89,65 & Ekonomis \\
\hline \multicolumn{3}{|c|}{ Rata-rata } & 87,08 & Ekonomis \\
\hline
\end{tabular}

Sumber :BPKAD Kabupaten Musi Banyuasin, Tahun 2020, data diolah 
Berdasarkan Tabel 7 di atas dapat dilihat bahwa perhitungan rasio ekonomis di atas dapat diketahui bahwa analisis rasio keuangan yang dihitung dengan menggunakan rasio ekonomis Tahun 2015 sebesar 80,59\% dimana rasio ekonomis menunjukkan bahwa sudah ekonomis dalam pengelolaan belanja daerah karena kurang dari 100\%. Rasio ekonomis pada Tahun 2016 dibandingkan pada tahun sebelumnya mengalami peningkatan rasio sebesar 90,61\% yang menunjukkan bahwa rasio tersebut masih dalam kategori ekonomis karena kurang dari $100 \%$. Pada Tahun 2017 rasio ekonomis sebesar 91,20\% mengalami kenaikan dari tahun sebelumnya, rasio tersebut tetap dikatakan ekonomis karena masih kurang dari 100\%. Pada Tahun 2018 rasio ekonomis sebesar 83,36\% mengalami penurunan dari tahun sebelumnya, rasio tersebut masih dalam kategori ekonomis karena masih kurang dari 100\%. Pada Tahun 2019 rasio ekonomis sebesar 89,65\% mengalami kenaikan dari tahun sebelumnya, rasio tersebut tetap bisa dikatakan ekonomis karena masih kurang dari 100\%. Rasio ekonomis Pemerintah Daerah Kabupaten Musi Banyuasin secara rata-rata sebesar $87,08 \%$ dengan kriteria ekonomis karena kurang dari $100 \%$. Hal ini dikarenakan oleh realisasi belanja daerah lebih kecil dari anggaran belanja daerah yang telah ditentukan yang kemudian juga berdampak pada belanja daerah yang tidak dapat terealisasi semuanya dengan baik. Dari Tahun 2015 sampai dengan 2019 hasil dari persentase rasio ekonomis tersebut sudah ekonomis, dari hasil wawancara dengan Kepala Bidang Akuntansi, membenarkan bahwa memang sudah ekonomis, hal ini dikarenakan adanya penyesuaian dari realisasi pendapatan daerah. Jika realisasi pendapatan besar maka belanja daerah juga besar dan sebaliknya. Dengan demikian sebaiknya Pemerintah Kabupaten Musi Banyuasin harus tetap optimal dalam pengelolaan belanja daerah.

\section{Analisis Rasio Efisiensi}

Efisiensi merupakan komponen dari konsep value for money, efisiensi diukur dengan antara rasio antara output dengan input. Semakin besar output dibandingkan input, maka semakin tinggi tingkat efisiensi suatu organisasi. Efisiensi adalah hubungan antara barang dan jasa (output) yang di hasilkan dengan sumber daya (in-put) yang digunakan untuk menghasilkan output tersebut. Suatu organisasi, program, atau kegiatan dikatakan efisien apabila mampu menghasilkan 
output tertentu dengan input serendah-rendahnya, atau dengan input tertentu mampu menghasilkan output sebesar-besarnya (spending well). Untuk dapat menghitung rasio efisiensi diperlukan data tentang realiasasi pendapatan dan belanja daerah. Rasio efesiensi dapat dihitung dengan rumus sebagai berikut:

$$
\text { Rasio Efisiensi }=\frac{\text { Realisasi Belanja Daerah }}{\text { Realisasi Pendapatan Daerah }} \times 100 \%
$$

Adapun kriteria penilaian efisiensi kinerja keuangan adalah sebagai berikut :

Tabel 8

Kriteria Efisiensi Kinerja Keuangan

\begin{tabular}{|c|c|}
\hline Persentase Kinerja Keuangan & Kriteria \\
\hline Kurang dari $100 \%$ & Efisien \\
Sama dengan $100 \%$ & Efisien Berimbang \\
Lebih dari $100 \%$ & Tidak Efisien \\
\hline
\end{tabular}

Berdasarkan rumus perhitungan rasio efesiensi kinerja keuangan, Penulis sajikan data tentang realisasi pendapatan dan belanja daerah Kabupaten Musi Banyuasin pada Tabel 9 di bawah ini:

Tabel 9

Realisasi Pendapatan dan Belanja Daerah Pemerintah Kabupaten Musi Banyuasin Tahun 2015 sampai dengan 2019

(Dalam Rupiah)

\begin{tabular}{|c|r|r|}
\hline Tahun & $\begin{array}{c}\text { Realisasi Pendapatan } \\
\text { Daerah }\end{array}$ & $\begin{array}{c}\text { Realisasi Belanja } \\
\text { Daerah }\end{array}$ \\
\hline \hline 2015 & 2.034 .401 .344 .567 & 2.096 .431 .426 .307 \\
\hline 2016 & 2.640 .255 .197 .404 & 2.280 .009 .346 .065 \\
\hline 2017 & 2.642 .776 .006 .641 & 2.340 .644 .994 .246 \\
\hline 2018 & 3.019 .699 .825 .935 & 2.569 .468 .000 .595 \\
\hline 2019 & 3.941 .909 .794 .940 & 3.160 .193 .342 .676 \\
\hline
\end{tabular}

Sumber :BPKAD Kabupaten Musi Banyuasin, Tahun 2020, data diolah

Berikut ini Penulis sajikan data tentang rekapitulasi perhitungan rasio efisiensi kinerja keuangan Kabupaten Musi Banyuasin Tahun 2015 sampai dengan 2019 pada Tabel 10 di bawah ini: 
Tabel 10

Rekapitulasi Perhitungan Rasio Efisiensi

Pemerintah Kabupaten Musi Banyuasin

Tahun 2015 sampai dengan 2019

(Dalam Rupiah)

\begin{tabular}{|c|c|c|c|c|}
\hline Tahun & $\begin{array}{c}\text { Realisasi } \\
\text { Pendapatan } \\
\text { Daerah }\end{array}$ & $\begin{array}{l}\text { Realisasi Belanja } \\
\text { Daerah }\end{array}$ & $\begin{array}{l}\% \text { Rasio } \\
\text { Efisiensi }\end{array}$ & Kriteria \\
\hline 2015 & 2.034 .401 .344 .567 & 2.096.431.426.307 & 103,05 & Tidak Efisien \\
\hline 2016 & 2.640 .255 .197 .404 & 2.280.009.346.065 & 86,36 & Efisien \\
\hline 2017 & 2.642.776.006.641 & 2.340.644.994.246 & 88,57 & Efisien \\
\hline 2018 & 3.019 .699 .825 .935 & 2.569 .468 .000 .595 & 85,09 & Efisien \\
\hline 2019 & 3.941 .909 .794 .940 & 3.160 .193 .342 .676 & 80,17 & Efisien \\
\hline \multicolumn{3}{|c|}{ Rata-rata } & 88,65 & Efisien \\
\hline
\end{tabular}

Sumber :BPKAD Kabupaten Musi Banyuasin, Tahun 2020, data diolah

Berdasarkan Tabel 10 di atas, dapat dilihat bahwa perhitungan rasio efisiensi kinerja keuangan Pemerintah Kabupaten Musi Banyuasin Tahun 2015 belum efisien. Hal ini dikarenakan realisasi pendapatan daerah sebesar Rp. 2.034.401.344.567 tidak mencukupi alokasi belanja daerah sebesar Rp. 2.096.431.426.307, hal ini disebabkan oleh tidak tercapainya target pendapatan asli daerah, dana perimbangan ataupun lain-lain pendapatan asli daerah yang sah serta Pemerintah Kabupaten Musi Banyuasin ada selisih lebih perhitungan anggaran (Silpa) tahun sebelumnya, sehingga belanja daerah dapat dipenuhi. Sedangkan pada Tahun 2016-2019 dalam kategori efisien. Hal ini dikarenakan pendapatan lebih besar dari pada alokasi belanja daerah, sehingga menghasilkan rasio yang efisien. Dengan demikian maka disimpulkan bahwa kinerja keuangan Pemerintah Kabupaten Musi Banyuasin dari Tahun 2015-2019 dalam kategori efisien dimana rata-rata rasio efisiensi hanya sebesar 88,65\%, yang berarti bahwa Pemerintah Kabupaten Musi Banyuasin mampu menggunakan sumber daya yang diperlukan serendah rendahnya. Efisiensi merupakan perbandingan antara output dan input. Kinerja Pemerintah Daerah dikatakan efisien apabila rasio yang dicapai kurang dari $100 \%$, atau semakin kecil rasio efesiensi yang dicapai, maka kinerjanya semakin baik. Tingkat efisiensi dalam mengelola keuangan dengan melihat 
perbandingan antara realisasi anggaran belanja dengan realisasi anggaran pendapatan.

\section{Analisis Rasio Efektivitas}

Efektivitas pada dasarnya berhubungan dengan pencapaian tujuan atau target kebijakan (hasil guna). Efektivitas merupakan hubungan keluaran dengan tujuan atau sasaran yang harus dicapai. Efektivitas terkait dengan hubungan antara hasil yang diharapkan dengan hasil yang sesungguhnya dicapai. Efektivitas merupakan hubungan antara output dengan tujuan. Semakin besar kontribusi output terhadap pencapaian tujuan, maka semakin efektif organisasi, program, atau kegiatan. Jika ekonomi berfokus pada input dan efisiensi berfokus pada output atau proses, maka efektivitas berfokus pada outcome (hasil). Rasio efektivitas dapat dihitung dengan rumus sebagai berikut:

Rasio Efektivitas $=\quad \frac{\text { Realisasi Pendapatan Daerah }}{\text { Anggaran Pendapatan Daerah }}$ X 100\%
berikut :

Adapun kriteria penilaian efektivitas kinerja keuangan adalah sebagai Tabel 11

Kriteria Efektivitas Kinerja Keuangan

\begin{tabular}{|c|c|}
\hline Persentase Kinerja Keuangan & Kriteria \\
\hline Kurang dari $100 \%$ & Tidak Efektif \\
Sama dengan $100 \%$ & Efektif Berimbang \\
Lebih dari $100 \%$ & Efektif \\
\hline
\end{tabular}

Sumber: Mahsun (2016)

Berdasarkan rumus perhitungan rasio efektivitas kinerja keuangan daerah, Penulis sajikan data tentang anggaran dan realiasi pendapatan daerah Kabupaten Musi Banyuasin pada Tabel 12 di bawah ini:

Tabel 12

Anggaran dan Realisasi Pendaptan Daerah

Tahun 2015 sampai dengan 2019

(Dalam Rupiah)

\begin{tabular}{|c|c|c|}
\hline Tahun & $\begin{array}{c}\text { Anggaran } \\
\text { Pendapatan Daerah }\end{array}$ & $\begin{array}{c}\text { Realisasi } \\
\text { Pendapatan Daerah }\end{array}$ \\
\hline \hline 2015 & 2.506 .193 .141 .320 & 2.034 .401 .344 .567 \\
\hline
\end{tabular}




\begin{tabular}{|c|c|c|}
\hline Tahun & $\begin{array}{c}\text { Anggaran } \\
\text { Pendapatan Daerah }\end{array}$ & $\begin{array}{c}\text { Realisasi } \\
\text { Pendapatan Daerah }\end{array}$ \\
\hline 2016 & 2.849 .225 .683 .981 & 2.640 .255 .197 .404 \\
\hline 2017 & 2.876 .720 .007 .058 & 2.642 .776 .006 .641 \\
\hline 2018 & 2.979 .978 .607 .000 & 3.019 .699 .825 .935 \\
\hline 2019 & 3.688 .474 .554 .548 & 3.941 .909 .794 .940 \\
\hline
\end{tabular}

Sumber :BPKAD Kabupaten Musi Banyuasin, Tahun 2020, data diolah

Berikut ini Penulis sajikan data tentang rekapitulasi perhitungan rasio efektivitas kinerja keuangan Pemerintah Kabupaten Musi Banyuasin Tahun 2015 sampai dengan 2019 pada Tabel 13 di bawah ini :

Tabel 13

Rekapitulasi Perhitungan Rasio Efektivitas Kinerja Keuangan Pemerintah Kabupaten Musi Banyuasin

Tahun 2015 sampai dengan 2019

(Dalam Rupiah)

\begin{tabular}{|c|c|c|c|c|}
\hline Tahun & $\begin{array}{c}\text { Anggaran } \\
\text { Pendapatan Daerah }\end{array}$ & $\begin{array}{c}\text { Realisasi } \\
\text { Pendapatan Daerah } \\
\end{array}$ & $\begin{array}{c}\% \text { Rasio } \\
\text { Efektivitas } \\
\end{array}$ & Kriteria \\
\hline 2015 & 2.506 .193 .141 .320 & 2.034 .401 .344 .567 & 81,17 & Tidak Efektif \\
\hline 2016 & 2.849.225.683.981 & 2.640.255.197.404 & 92,67 & Tidak Efektif \\
\hline 2017 & 2.876 .720 .007 .058 & 2.642 .776 .006 .641 & 91,87 & Tidak Efektif \\
\hline 2018 & 2.979.978.607.000 & 3.019 .699 .825 .935 & 101,33 & Efektif \\
\hline 2019 & 3.688 .474 .554 .548 & 3.941 .909 .794 .940 & 106,87 & Efektif \\
\hline \multicolumn{3}{|c|}{$\begin{array}{ll} & \text { Rata-rata } \\
\end{array}$} & 94,78 & Tidak Efektif \\
\hline
\end{tabular}

Sumber :BPKAD Kabupaten Musi Banyuasin, Tahun 2020, data diolah

Kinerja pengelolaan keuangan daerah ditinjau dari rasio efektivitas Pemerintah Daerah Kabupaten Musi Banyuasin dari Tahun 2015 sampai dengan 2019 secara rata-rata sebesar 94,78\% dengan kriteria tidak efektif. Hal ini berarti Pemerintah Kabupaten Musi Banyuasin belum baik dalam pengelolaan pendapatan. Berdasarkan wawancara dengan Kepala Bagian Akuntansi Badan Pengelola Keuangan dan aset Daerah Kabupaten Musi Banyuasin, bahwa efektivitas keuangan 2015-2017 tidak pernah mencapai lebih dari 100\% serta 2018-2019 lebih dari $100 \%$ dikarenakan ada penerimaan dana yang tidak dianggarkan di awal periode. 


\section{Implikasi Penelitian}

Value for Money merupakan konsep pengelolaan organisasi sektor publik yang mendasar pada tiga elemen yaitu ekonomis, efisiensi dan efektivitas. Untuk bisa mengukur tingkat ekonomis, efisiensi dan efektivitas organisasi pemerintahan harus dapat mengetahui tingkat input, output dan outcome. Berikut ini Penulis sajikan data tentang tingkat ekonomis, efisiensi dan efektivitas kinerja keuangan Pemerintah Kabupaten Musi Banyuasin pada Tabel 14.

Tabel 14

Rekapitulasi Perhitungan Rasio Ekonomis, Efektivitas dan Efisiensi Pemerintah Kabupaten Musi Banyuasin Tahun 2015 sampai dengan 2019 (Dalam Rupiah)

\begin{tabular}{|c|c|c|c|c|c|c|}
\hline \multirow{2}{*}{ Tahun } & \multicolumn{2}{|c|}{ Ekonomis } & \multicolumn{2}{|c|}{ Efisiensi } & \multicolumn{2}{|c|}{ Efektivitas } \\
\hline & Rasio & Kriteria & Rasio & Kriteria & Rasio & Kriteria \\
\hline 2015 & 80,59 & Ekonomis & 103,05 & $\begin{array}{c}\text { Tidak } \\
\text { Efisien }\end{array}$ & 81,17 & $\begin{array}{c}\text { Tidak } \\
\text { Efektif }\end{array}$ \\
\hline 2016 & 90,61 & Ekonomis & 86,36 & Efisien & 92,67 & $\begin{array}{l}\text { Tidak } \\
\text { Efektif }\end{array}$ \\
\hline 2017 & 91,20 & Ekonomis & 88,57 & Efisien & 91,87 & $\begin{array}{c}\text { Tidak } \\
\text { Efektif }\end{array}$ \\
\hline 2018 & 83,36 & Ekonomis & 85,09 & Efisien & 101,33 & Efektif \\
\hline 2019 & 89,65 & Ekonomis & 80,17 & Efisien & 106,87 & Efektif \\
\hline Rata-rata & 87,08 & Ekonomis & 88,65 & Efisien & 94,78 & $\begin{array}{c}\text { Tidak } \\
\text { Efektif }\end{array}$ \\
\hline
\end{tabular}

Sumber :BPKAD Kabupaten Musi Banyuasin, Tahun 2020, data diolah

Berdasarkan data pada Tabel 14 di atas, dapat dijelaskan bahwa kinerja keunagan Pemerintah Daerah Kabupaten Musi Banyuasin berdasarkan rasio ekonomis Pemerintah Daerah Kabupaten Musi Banyuasin secara rata-rata sebesar $87,08 \%$ dengan kriteria ekonomis karena kurang dari 100\%. Hal ini dikarenakan realisasi belanja daerah lebih kecil dari anggaran belanja daerah yang telah ditentukan yang kemudian juga berdampak pada belanja daerah yang tidak dapat terealisasi semuanya dengan baik. Dari Tahun 2015 sampai dengan 2019 hasil dari persentase rasio ekonomis tersebut sudah ekonomis, hal ini dikarenakan adanya penyesuaian dari realisasi pendapatan daerah. Jika realisasi pendapatan besar maka 
belanja daerah juga besar dan sebaliknya. Dengan demikian sebaiknya Pemerintah Kabupaten Musi Banyuasin harus tetap optimal dalam pengelolaan belanja daerah.

Kinerja keuangan Pemerintah Kabupaten Musi Banyuasin berdasarkan rasio efisiensi dari Tahun 2015-2019 dalam kategori efisien dimana rata-rata rasio efisiensi hanya sebesar 88,65\%, yang berarti bahwa Pemerintah Kabupaten Musi Banyuasin mampu menggunakan sumber daya yang diperlukan serendah rendahnya. Efisiensi merupakan perbandingan antara output dan input. Kinerja Pemerintah Daerah dikatakan efisien apabila rasio yang dicapai kurang dari $100 \%$, atau semakin kecil rasio efesiensi yang dicapai, maka kinerjanya semakin baik. Tingkat efisiensi dalam mengelola keuangan dengan melihat perbandingan antara realisasi anggaran belanja dengan realisasi anggaran pendapatan. Kinerja pengelolaan keuangan daerah ditinjau dari rasio efektivitas Pemerintah Daerah Kabupaten Musi Banyuasin dari Tahun 2015 sampai dengan 2019 secara rata-rata sebesar 94,78\% dengan kriteria tidak efektif. Hal ini berarti Pemerintah Kabupaten Musi Banyuasin belum baik dalam pengelolaan pendapatan. Dengan demikian, maka Penulis dapat menyimpulkan bahwa kinerja keuangan Pemerintah Kabupaten Musi Banyuasin ditinjau dari konsep Value for Money dari Tahun 2015 sampai dengan 2019 berada dalam kategori cukup baik, karena rasio ekonomis dan efisiensi sudah baik tetapi untuk rasio efektivitas belum baik.

\section{SIMPULAN}

Rasio ekonomis pada Pemerintah Kabupaten Musi Banyuasin menunjukkan kinerja pemerintah daerah dengan rata-rata rasio sebesar $87,08 \%$, menunjukkan bahwa rasio ini bernilai ekonomis. Oleh karena itu, untuk indikator rasio ekonomis Pemerintah Kabupaten Musi Banyuasin sudah mencapai kinerja yang baik, dimana telah berhasil mengelola penggunaan anggaran belanja dengan baik. Rasio efisiensi kinerja Pemerintah Kabupaten Musi Banyuasin cukup baik, meskipun pada Tahun 2015 menunjukkan rasio yang tidak efisien. Namun secara keseluruhan kinerja Pemerintah Kabupaten Musi Banyuasin telah efisien, yang berarti bahwa pemerintah mampu menggunakan sumber daya yang diperlukan dengan minimum untuk mencapai target yang maksimum. Oleh sebab itu, suatu organisasi akan di 
katakan efisien apabila rasio yang dicapai kurang dari 100\% atau semakin kecil rasio yang diperoleh, maka kinerjanya semakin efisien. Rasio efektifitas pada Pemerintah Kabupaten Musi Banyuasin dengan rata-rata nilai rasio 94,78\% rasio efektifitas yang bernilai $<100 \%$ menunjukkan bahwa kinerja pemerintah Kabupaten Musi Banyuasin pada tahun tersebut dinilai tidak efektif.

Pemerintah Kabupaten Musi Banyuasin dapat menerapkan konsep Value for Money sebagai salah satu metode yang dapat digunakan untuk menilai suatu perencanaan yang dibuat oleh Pemerintah Kabupaten Musi Banyuasin terhadap realisasinya. Hasil perhitungan rasio ekonomis yang diterima oleh Pemerintah Kabupaten Musi Banyuasin baik, tetapi Pemerintah Kabupaten Musi Banyuasin harus dapat mengendalikan biaya atau belanja yang dikeluarkan yang seharusnya disesuaikan dengan nominal yang telah dianggarkan agar tidak menimbulkan pengeluaran yang boros dan tidak produktif, terutama pengeluaran yang tidak bermanfaat bagi kepentingan publik agar rasio ini dapat tetap bertahan atau bahkan dapat lebih ditingkatkan lagi. Hasil perhitungan rasio efisiensi sudah menunjukkan kinerja yang baik, tetapi Pemerintah Kabupaten Musi Banyuasin perlu meninjau perencanaan belanja daerah sehingga tidak terjadi lagi rasio tidak efisien. Pemerintah Kabupaten Musi Banyuasin perlu meninjau penentuan target anggaran di masa yang akan datang dan dapat menyusun strategi yang tepat agar tercapai tujuan pembangunan dan pengembangan daerah Kabupaten Musi Banyuasin. agar Kabupaten Musi Banyuasin dapat memperoleh rasio yang lebih baik dari sebelumnya dan terciptanya good government dan sukses dalam membangun daerahnya.

\section{DAFTAR PUSTAKA}

Bastian, Indra. 2017. Akuntansi Sektor Publik: Suatu Pengantar. Jakarta: Erlangga Halim, Abdullah. 2017. Akuntansi Keuangan Daerah. Jakarta:, Salemba Empat.

Indrayani, Khairunnisa. 2018. Analisis Pengukuran Kinerja Dengan Menggunakan Konsep Value For Money Pada Pemerintah Kota Lhokseumawe (Studi Kasus Pada Dpkad Kota Lhokseumawe Periode 2014-2016). Jurnal Akuntansi dan Keuangan. Vol. 6. Nomor 1. Universitas Malikussaleh. Aceh Utara. 
Khikma, Alayyal. 2014. Pengukuran Kinerja Pemerintah Daerah Kabupaten Lamongan Berdasarkan Konsep Value For Money. Jurnal Akunesa. Vol. 3 Nomor 1. Universitas Negeri Surabaya. Surabaya.

Mardiasmo. 2016. Akuntansi Sektor Publik. Yogyakarta: Andi

Mahmudi. 2016. Analisis Laporan Keuangan Pemerintah Daerah. Yogyakarta: Unit Penerbit dan Percetakan STIM YKPN.

Nordiawan, Dedi. 2016. Akuntansi Sektor Publik. Jakarta: Salemba Empat

Nur, Astria Jannah Dien, Jantje Tinangon dan Stanley Walandouw. 2015. Analisis Laporan Realisasi Anggaran Untuk Menilai Kinerja Keuangan pada Kantor Dinas Pendapatan Daerah Kota Bitung. Jurnal EMBA Vol 3 Nomor 1. Universitas Sam Ratulangi

Peraturan Pemerintah Nomor 58 Tahun 2005 Tentang Pengelolaan Keuangan Daerah.

Peraturan Menteri Dalam Negeri No 26 Tahun 2006 Tentang Pedoman Penyusunan APBD.

Peraturan Menteri Dalam Negeri Nomor 13 Tahun 2006 Tentang Pedoman Pengelolaan Keuangan Daerah.

Ridwan. 2012. Skala Pengukuran Variabel-variabel Penelitian. Bandung: Alfabeta

Sholihah, Ratna. 2011. Analisis Kemampuan Kemandirian Keuangan Daerah dan Pengaruhnya Terhadap Pertumbuhan Ekonomi Kabupaten Wonogiri Tahun Anggaran 2000-2009. Skripsi Tidak Dipublikasikan. Universitas Sebelas Maret Surakarta

Sugiyono. 2012. Metode Penelitian Kuantitatif Kualitatif dan R\&D. Bandung: Alfabeta 